\title{
Detection of Aflatoxins B1 from Layer and Broiler Feed Samples Collected from Different Cities of Punjab, Pakistan Khadija Summia ${ }^{1}$, Roheela Yasmeen ${ }^{*}$, Naseem Zahra ${ }^{2}$ \\ ${ }^{1}$ Department of Biology, Lahore Garrison University, Lahore, Pakistan; ${ }^{2}$ Food and Biotechnology Research Centre, PCSIR, Laboratories Complex, Ferozepur Road, Labore, Pakistan.
}

\begin{abstract}
Mycotoxins are secondary metabolites produced by fungi results in contamination of food, cause diseases so has major impact on animals and human health. While aflatoxins are type of poisonous mycotoxins produced by Aspergillus species. Present study was conducted to see levels of aflatoxins that are present in poultry feed. A total of 50 feed samples from layer and broiler farms were collected from five different cities of Punjab such as Lahore, Sialkot, Gujranwala, Sheikhupura and Kasur. Ten samples were collected from each city. Upon quantification by Thin Liquid Chromatography (TLC) method the contamination was detected in 24 samples out of which 11 (22\%) were contaminated beyond the permissible range and $13(26 \%)$ were contaminated within the permissible range. Positive samples were run for the assessment of all different types of aflatoxins such as B1, B2, G1 and G2. However, only aflatoxin B1 was detected in the positive samples. The highest percentage of contaminated samples were collected from Kasur city and broiler feed samples were found more contaminated $(\mathrm{p}<0.05)$ as compared to layer feed samples when statistically analyzed by independent sample $T$ test. Different detoxification methods such as physical and chemical methods were also compared. The most effective physical method of detoxification was noticed heating upto $250^{\circ} \mathrm{C}$ for 10 minutes as it reduce aflatoxin concentration up to $58 \%$. While, in the chemical methods the Hydrochloric acid was a highly effective chemical for detoxification as it reduced aflatoxin level up to $58.4 \%$ only with its $0.5 \%$ concentration. Other chemicals were also effective but they were required in higher concentrations to show their efficacy which can affect the nutritive value of the feed samples. It was concluded by the study that broiler feed samples collected from Kasur were more contaminated that may be due to poor storage conditions of feed. It is recommended that improvement in storage conditions and regular monitoring is required by feed authorities so that contamination of aflatoxins can be reduced.
\end{abstract}

Keywords | Aflatoxins, Detoxification, Laying hen, Broiler, Contamination

Received | July 21, 2021; Accepted | August 08, 2021; Published | October 01, 2021

*Correspondence | Roheela Yasmeen, Department of Biology, Lahore Garrison University, Lahore, Pakistan; Email: raheelasattar44@gmail.com

Citation Summia K, Yasmeen R, Zahra N (2021). Detection of aflatoxins b1 from layer and broiler feed samples collected from different cities of Punjab,

Pakistan. J. Anim. Health Prod. 9(4): 435-442.

DOI | http://dx.doi.org/10.17582/journal.jahp/2021/9.4.435.442

ISSN | 2308-2801

Copyright (C) 2021 Yasmeen et al. This is an open access article distributed under the Creative Commons Attribution License, which permits unrestricted use, distribution, and reproduction in any medium, provided the original work is properly cited.

\section{INTRODUCTION}

$\mathrm{T}$ he poultry sector in Pakistan is flourished as a big industry that is sharing almost $26.8 \%, 5.76 \%$ and $1.26 \%$ respectively to total meat production, agricultural sector and overall Gross Domestic Production (GOP, 2014). The poultry feed of birds is by and large composed of a variety of feed elements along with cereal grains, soybean meal, animal derivative food, fats, and vitamin and mineral premixes (Anjum et al., 2014). Most of the feed ingredients found in typical poultry rations can be contaminated by harmful mycotoxins that are consumed by birds and results in serious consequences. The mycotoxins are produced by fungus in feed and potentially carcinogenic compounds that prove harmful in humans and animals when they are exposed to them (Van Egmond et al., 2007). These my- 
cotoxins are favorably produced at a temperature of 12$40^{\circ} \mathrm{C}$ and require 3-18\% moisture (Duncan and Hagler, 2008) and divided into six categories: aflatoxins, patulin, ochratoxins, zearalenone, trichothecenes, and ergot alkaloids (Jestoi, 2008). Certain mycotoxins can cause human and animal death (Gunterus et al., 2007). In all these six categories only ochratoxins and aflatoxins are considered to be the most important in the poultry industry (Perrone et al., 2007; Abidin et al., 2011).

Aflatoxins are metabolites produced through some fungal strains of the genus Aspergillus such as A. flavus and $A$. parasiticus. More than 18 aflatoxins from various fungal species have been identified, aflatoxin B1, B2, G1, and G2 are considered as major contaminant of agricultural commodities. These aflatoxins have the ability to pose a greater risk to poultry by impairing weight gain, feed intake, feed conversion efficacy, and egg production (Ortatatli et al., 2005; Shareef et al., 2008). Poultry feeds are primarily composed of energy and protein rich feedstuffs such as corn, rice and peanuts, cottonseed, etc. which are the most susceptible ingredients for the growth of $A$. flavus. This particular strain is generally liable for aflatoxin B1 and aflatoxin $\mathrm{B} 2$ production, whereas $A$. parasiticus produces aflatoxin B1, B2, G1 and G2 (Agag, 2004).

Among these, aflatoxin B1 (AFB1) is of great concern due to its carcinogenic, mutagenic, teratogenic (Zinedine et al., 2007; Shi et al., 2009), immunosuppressive (Sahoo and Mukherjee, 2001; A1-Hammadi et al., 2014) and growth inhibitory effects (Khan et al., 2010) particularly in humans (Owino et al., 2007). AFB1 is usually the major aflatoxin produced by toxigenic strains (Qazi and Fyyaz, 2006) and categorized as class I carcinogen for humans by International Agency for Research on Cancer.

The aflatoxins are very important for commercial poultry as they not only reduce the production performance of birds but also be responsible for the lower growth rates, and feed efficiency losses (Howorth et al., 1976; Fandohan et al., 2005). Anorexia with a slowed development rate, poor feed utilization, decreased egg production, and increased mortality are all symptoms of aflatoxicosis in poultry. It is also reason for lowered immunological function, hepatotoxicosis, bleeding, teratogenesis, carcinogenesis, and mutagenesis (Oguz, 2012).

Detoxification of aflatoxins in foods and animal feeds is in practice although the detoxified product only be suitable for animal feed purposes and not for human consumption (Gunterus et al., 2007). Recently various physical and chemical methods are in practice to degrade aflatoxins (Neal et al., 2001; Kabak et al., 2006). The detoxification of aflatoxin B1 may be affected by alkali solutions according to their concentration but it is degraded greatly by acid addition (WenLi et al., 2008). Absorption of aflatoxins from feed may be successfully completed with the aid of substances like bentonite, zeolite, hydrated calcium sodium aluminosilicate, kaolin, and so forth. These materials display poor efficacy when contamination is on large scale and additionally soak up nutrients and different vitamins from feed which results in a poor feed conversion ratio (Piva et al., 2000).

In the world, Pakistan is recognized as $11^{\text {th }}$ largest country in the poultry production. So, there is a need to update the knowledge about aflatoxins from poultry farms on regular basis. There is also need to report data on levels of aflatoxins in poultry feed from Lahore and some other major cities to compare spatio-temporal differences, their managerial practices and to find best storage practices. This study endorsed need of a synergistic approach to support poultry farmers and highlight the contamination levels in feed for regulatory bodies to initiate strategic policies as control measures. The present research work was designed to detect levels of aflatoxins in the poultry feed samples collected from different cities of Punjab (Lahore, Sialkot, Gujranwala, Sheikhupura and Kasur), Pakistan using the TLC method. The detected levels will also be compared with European standards and detoxification of aflatoxin's contaminated samples were also carried out by using different physical and chemical methods. This will facilitate by finding the best detoxification practices which can be used to eradicate misuse of poultry feed and to improve storage conditions.

\section{MATERIALS AND METHODS}

\section{Collection OF SAMPLES AND STUDYING SITE}

Fifty poultry feed samples ten from layer and forty broiler poultry farms were collected in the period of July 2020 to March 2021 from five cities of Punjab such as Lahore, Sialkot, Gujranwala, Sheikhupura and Kasur. All the samples that were collected from different cities were properly labelled as Lahore (A1 to A10), Sialkot (B1 to B10), Gujranwala (C1 to C10), Sheikhupura (D1 to D10) and Kasur (E1 to E10). The study was conducted in Food and Biotechnology Research Centre of Pakistan Council of Scientific and Industrial Research Laboratories Complex, Lahore.

\section{Temperature and Humidity}

Abiotic factors such as temperature and humidity were also recorded during collection of samples.

Preparation of SAMples for aflatoxin QUANTIFICATION

$100 \mathrm{gm}$ of the samples were ground through Romer grind- 
ing mill then $50 \mathrm{gm}$ of test portion was taken from this mixture into $500 \mathrm{~mL}$ conical flask and $25 \mathrm{~mL}$ of water and $225 \mathrm{~mL}$ chloroform were added. After shaking for $30 \mathrm{~min}$ on a wrist action shaker, the sample was filtered through filter paper. The filtrate was collected in a beaker which was then subjected to evaporation on heavy-duty hot plate. All the samples were prepared according to methods of Begum et al. (1985). All the samples were run in triplicates along with standard solutions to assure the quality of the method.

\section{Processing of SAMPles on TLC PLATE}

Spotting was done with spots of different dilutions such as $5,10,15,20$ and $25 \mu \mathrm{L}$ on TLC plate at a distance of 1.5 $\mathrm{cm}$ from the base. The standard spots were also made by following the methods of Begum et al. (1985), Romer and Campbell (1976). The plate was removed, dried and finally subjected to a UV light scanner of $365 \mathrm{~nm}$ for the presence or absence of aflatoxins (B1, B2, G1, and G2). Later on quantification was also carried out and sample spot fluorescence intensities were compared with the standard spot fluorescence intensities and the concentrations of aflatoxins were calculated by the formula used by Saeed et al. (2020).

\section{DETOXIFICATION BY PHYSICAL AND CHEMICAL}

\section{METHODS}

Detoxification of contaminated and aflatoxin positive samples were carried out by physical (Heating and boiling) and chemical methods as proceeded by Zahra et al. (2012). Heating and boiling with varying temperatures and time was applied to five most contaminated samples from each city. Molar solutions of different chemicals (hydrochloric acid, citric acid, sodium Bisulphate, calcium hydroxide, sodium hypochlorite, sodium chloride, acetone, ethanol, and ammonia) were also prepared and used for the detoxification of highly contaminated samples. Later, on quantification of a detoxified sample of aflatoxins was carried by TLC estimation through UV light scanner and calculation was made by using formula of Saeed et al. (2020).

\section{STATISTICAL ANALYSIS}

Statistical analysis was performed by independent and paired sample T-test in IBM SPSS Statistics 21.

\section{RESULTS}

Out of 50 samples collected from different cities 24 (48\%) samples were found contaminated and of which 13 (26\%) were contaminated within the permissible range and 11 (22\%) were contaminated beyond the permissible range. The samples beyond the permissible range were totally unfit for consumption and have high aflatoxin levels ranged from 12.08 to $16.65 \mu \mathrm{g} / \mathrm{kg}$ and can cause serious health problems (Table 1). The samples within the permissible range can be used for birds as they were under the tolerant range. The tolerant range limit of aflatoxins in poultry feed is noticed as $10 \mu \mathrm{g} / \mathrm{kg}$ according to EU (2010). The AFB1 was detected in 24 samples because it is the most potent strain of aflatoxins. Whereas B2, G1 and G2 were not detected in any sample.

Total 10 samples from each city were collected and highest percentage of contamination recorded in Kasur city which was $60 \%$. The minimum concentration of aflatoxins detected was $3.43 \mu \mathrm{g} / \mathrm{kg}$ from Sialkot whereas the maximum concentration was $16.65 \mu \mathrm{g} / \mathrm{kg}$ was from Gujranwala city (Table 1).

Based on varying poultry houses aflatoxin analysis was also carried out in layer houses feed. Out of 50 feed samples only 10 feed samples were from laying houses and 40 were from broiler feed samples. It was noticed laying hen feed samples were less contaminated than broiler feed samples. In layer houses only 4 samples out of 10 were contaminated and 6 were uncontaminated. Out of 4 only 1 sample was beyond the permissible range and 3 were within permissible range (Table 2). In 40 broiler feed samples 10 samples were within the permissible range and 10 were beyond permissible range. The uncontaminated samples were 20 . The percentage of each contaminated and uncontaminated samples was $50 \%$ and details of broiler feed samples were shown in Table 3 . The contamination percentage of broiler feed was $50 \%$ and in laying hen feed samples was $40 \%$. Independent sample $\mathrm{T}$ test was used to compare aflatoxin levels in layer and broiler houses and significantly higher contamination was recorded for broiler houses as compared to layer houses at $<0.05 \mathrm{p}$ value.

Heating and boiling were two physical methods which presently used for the detoxification of five highly contaminated samples. Three selected samples were heated at different temperatures and for varying period time. The highest reduction percentage was noticed as $58 \%$ at $250^{\circ} \mathrm{C}$ for 10 minutes. In case of boiling highest reduction percentage $(51.5 \%)$ was recorded for a sample that boiled at 20 minutes (Table 4). Different chemicals with different concentrations were also applied in the present study such as hydrochloric acid, citric acid, sodium bisulphate, calcium hydroxide, sodium hypochlorite, sodium chloride, acetone, ethanol, and ammonia.

Test solutions were also run with similar concentrations but most of the chemicals did not showed any results at their low concentrations as compared to $\mathrm{HCl}$ which showed $58.4 \%$ reduction with $0.5 \%$ solution while sodium bisulphate showed only $16 \%$ reduction at its $1 \%$ solution (Table 5). Chemicals like calcium hydroxide and ammonia 
Table 1: Levels of aflatoxins detected in feed samples collected from different cities

$\begin{array}{lllllllll}\text { Aflatoxins } & \text { Cities } & \begin{array}{l}\text { Total No. of } \\ \text { samples }\end{array} & \begin{array}{l}\text { No. of Contaminated } \\ \text { Samples }\end{array} & \begin{array}{l}\text { Contamination } \\ \text { detected \% }\end{array} & \begin{array}{l}\text { Max } \\ \boldsymbol{\mu g} / \mathbf{g}\end{array} & \begin{array}{l}\text { Min } \\ \boldsymbol{\mu g} / \mathbf{k g}\end{array} & \begin{array}{l}{ }^{*} \text { EU permissible } \\ \text { limit in } \boldsymbol{\mu g} / \mathbf{g}\end{array} \\ \text { Total B1 } & \text { Lahore } & 10 & 5 & 50 \% & 12.08 & 4.25 & \\ \text { AF } & \text { Sialkot } & 10 & 5 & 50 \% & 15.12 & 3.43 & \\ & \text { Gujranwala } & 10 & 4 & 40 \% & 16.65 & 3.84 & \\ & \text { Sheikhupura } & 10 & 4 & 40 \% & 14.47 & 3.87 & 10 \\ \text { Total } & \text { Kasur } & 10 & 6 & 60 \% & 14.71 & 3.89 & & \\ & & 50 & 24 & 48 \% & 16.65 & 3.43 & \end{array}$

*EU permissible limit in $\mu \mathrm{g} / \mathrm{g}$ (EU 2010): Aflatoxin: AF

Table 2: Number of layer hen feed samples contaminated by aflatoxins

\begin{tabular}{lllll} 
Cities & $\begin{array}{l}\text { No. of layer } \\
\text { feed samples }\end{array}$ & $\begin{array}{l}\text { No. of contaminated } \\
\text { samples }\end{array}$ & $\begin{array}{l}\text { Contaminated samples } \\
\text { Within permissible range }\end{array}$ & $\begin{array}{l}\text { Contaminated samples } \\
\text { Beyond permissible Range }\end{array}$ \\
\hline Lahore & 3 & 1 & 1 & 0 \\
\hline Sialkot & 2 & 1 & 0 & 1 \\
Gujranwala & 1 & 1 & 1 & 0 \\
Sheikhupura & 2 & 1 & 1 & 0 \\
Kasur & 2 & 0 & 0 & 0 \\
Total & 10 & 4 & 3 & 1 \\
\hline
\end{tabular}

Table 3: Number of broiler feed samples contaminated by aflatoxins

\begin{tabular}{lllll} 
Cities & $\begin{array}{l}\text { No. of broiler } \\
\text { feed samples }\end{array}$ & $\begin{array}{l}\text { Total No. of contaminated } \\
\text { samples }\end{array}$ & $\begin{array}{l}\text { Contaminated samples } \\
\text { Within permissible range }\end{array}$ & $\begin{array}{l}\text { Contaminated samples } \\
\text { Beyond permissible Range }\end{array}$ \\
\hline Lahore & 7 & 4 & 1 & 3 \\
\hline Sialkot & 8 & 4 & 2 & 2 \\
Gujranwala & 9 & 3 & 1 & 2 \\
Sheikhupura & 8 & 4 & 3 & 1 \\
Kasur & 8 & 5 & 3 & 2 \\
Total & 40 & 20 & 10 & 10
\end{tabular}

Table 4: Detoxification by physical methods

\begin{tabular}{lllllll}
$\begin{array}{l}\text { Sr. } \\
\text { No. }\end{array}$ & Cities & Sample & Physical method & $\begin{array}{l}\text { Initial Conc. } \\
\boldsymbol{\mu g} / \mathbf{k g} \\
\text { before detoxification }\end{array}$ & $\begin{array}{l}\text { Final Conc. } \\
\mathbf{\mu g} / \mathbf{k g} \\
\text { after detoxification }\end{array}$ & $\begin{array}{l}\text { Reduction } \\
\text { \%age }\end{array}$ \\
\hline 1 & Lahore & A6 & Heat at $120^{\circ} \mathrm{C}, 10 \mathrm{~min}$ & 12.08 & 6.04 & $50 \%$ \\
\hline 2 & Sialkot & B9 & Heat up to $200^{\circ} \mathrm{C}, 10 \mathrm{~min}$ & 15.12 & 8.57 & $43 \%$ \\
\hline 3 & Gujranwala & C7 & Heat up to $250^{\circ} \mathrm{C}, 10 \mathrm{~min}$ & 16.65 & 6.98 & $58 \%$ \\
\hline 4 & Sheikhupura & D6 & Boiling for 10 min & 14.47 & 7.98 & $44.8 \%$ \\
\hline 5 & Kasur & E3 & Boiling for 20 min & 14.71 & 7.12 & $51.5 \%$ \\
\hline
\end{tabular}

Table 5: Detoxification by chemical methods

\begin{tabular}{|c|c|c|c|c|c|}
\hline Cities & Sample & $\begin{array}{l}\text { Initial conc. } \mu \mathrm{g} / \mathrm{kg} \\
\text { before detoxification }\end{array}$ & $\begin{array}{l}\text { Chemical } \\
\text { Solutions }\end{array}$ & $\begin{array}{l}\text { Final conc. } \mu \mathrm{g} / \mathrm{kg} \\
\text { after detoxification }\end{array}$ & Reduction \% \\
\hline \multirow{3}{*}{ Lahore } & \multirow{3}{*}{ A6 } & \multirow{3}{*}{12.08} & $0.1 \% \mathrm{HCl}$ & 7.45 & $38.3 \%$ \\
\hline & & & $2 \% \mathrm{NaHSO}_{4}$ & 8.64 & $28.4 \%$ \\
\hline & & & $2 \% \mathrm{NaClO}$ & 4.83 & $60 \%$ \\
\hline \multirow{3}{*}{ Sialkot } & \multirow{3}{*}{ B9 } & \multirow{3}{*}{15.12} & $0.3 \% \mathrm{HCl}$ & 8.02 & $46.95 \%$ \\
\hline & & & $3 \% \mathrm{NaHSO}_{4}$ & 9.52 & $37 \%$ \\
\hline & & & $0.1 \% \mathrm{NaCl}$ & 2.26 & $15 \%$ \\
\hline
\end{tabular}

December 2021 | Volume 9 | Issue 4 | Page 438 


\begin{tabular}{|c|c|c|c|c|c|}
\hline \multirow{3}{*}{ Gujranwala } & \multirow{3}{*}{$\mathrm{C} 7$} & \multirow{3}{*}{16.65} & $0.5 \% \mathrm{HCl}$ & 6.91 & $58.4 \%$ \\
\hline & & & $1 \% \mathrm{NaHSO}_{4}$ & 13.9 & $16 \%$ \\
\hline & & & 99\% Acetone & 7.24 & $56.5 \%$ \\
\hline \multirow{3}{*}{ Sheikhupura } & \multirow{3}{*}{ D6 } & \multirow{3}{*}{14.47} & $10 \%$ Citric acid & 8.10 & $44 \%$ \\
\hline & & & $5 \% \mathrm{Ca}(\mathrm{OH})_{2}$ & 6.21 & $57 \%$ \\
\hline & & & $96 \%$ Ethanol & 6.1 & $57 \%$ \\
\hline \multirow{3}{*}{ Kasur } & \multirow{3}{*}{ E3 } & \multirow{3}{*}{14.71} & $30 \%$ Citric acid & 6.72 & $54.3 \%$ \\
\hline & & & $50 \% \mathrm{Ca}(\mathrm{OH})_{2}$ & 5.72 & $61.1 \%$ \\
\hline & & & 5\% Ammonia & 4.95 & $66.3 \%$ \\
\hline
\end{tabular}

showed a reduction in aflatoxins at their 5\% solution. Hydrochloric acid was highly appreciated for its detoxifying abilities. It showed a remarkable reduction percentage at its lower concentrations like $0.1,0.3$ and $0.5 \%$ (Table 5). The higher the concentration of chemicals the more risk to lower of nutritive value of the feed. Therefore the chemicals which showed remarkable reduction percentage at their low concentrations were comparatively considered more favorable for the detoxification. Physical and chemical degradation were also analyzed statistically by paired sample $\mathrm{T}$ test and significant differences were noticed in initial and final detoxification levels of the aflatoxins at $<0.05 \mathrm{p}$ value.

Abiotic factors such as temperature and humidity were also noticed during collection of samples. Temperature ranging from $35-39,28-30,15-21,7-11,11-13$ and $18-$ $20{ }^{\circ} \mathrm{C}$ while relative humidity $56-70,52-67,55-76,88-$ $100,83-100$ and 54-76 percent was recorded during July, September, November, December, January and February respectively. A higher levels of aflatoxins was recorded in samples collected in month of July and September as compared to other months (data not shown).

\section{DISCUSSION}

In the present study total of 50 feed samples collected from both broiler and layer houses were studied and the percentage of contaminated samples were recorded as $48 \%$ while, $22 \%$ of the samples have aflatoxins beyond the permissible range. However, a study conducted in Croatia showed $38.1 \%$ total contaminated samples, and $28.8 \%$ of the samples containing aflatoxin in levels higher than the maximal permitted levels (Pleadin et al., 2012). The maximum value of the aflatoxins detected in our study which was $16.65 \mu \mathrm{g} / \mathrm{kg}$ found very low as compared to $2,072 \mu \mathrm{g} / \mathrm{kg}$ that mentioned by Pleadin et al. (2012). So, it was noticed the detected levels of aflatoxins in different cities of Punjab were lower than the study conducted in Croatia, Europe. Similarly, Becha and Devi (2013), did a study in Kerala and 709 poultry feed samples were collected for the detection of aflatoxin levels which was ranged from 1 to $400 \mathrm{ppb}$ and found higher than our reported levels of aflatoxins. In 1991 the Hegazy et al. collected 1,175 poultry feed samples from different farms for the detection of aflatoxin. In all studied samples $30.7 \%$ proved positive for aflatoxin with a concentration ranging from 1 to 2,000 ppb. Although, in the present study the $48 \%$ samples were positive ranging from $3.43 \mu \mathrm{g} / \mathrm{kg}$ to $16.65 \mu \mathrm{g} / \mathrm{kg}$ which was lower than mentioned study.

A comparative study between layer and broiler feed was performed by Raphael et al. (2013) in Cameroon. Almost 93.3\% broiler and $83.0 \%$ layer feeds samples were positive while in our existing study $50 \%$ and $40 \%$ were recorded for the broiler and layer feed samples. The reported maximum concentrations $52 \mu \mathrm{g} / \mathrm{kg}$ for broiler feed and $23 \mu \mathrm{g} / \mathrm{kg}$ for layer feed also found higher as compared to our existing findings. The highest aflatoxin contents were reported as $16.8 \mu \mathrm{g} / \mathrm{kg}$ from Western High Plateau and in Rainforest agro-ecological zones in broiler feed samples was comparable to our present study (Kana et al., 2013). Poor growth rate and reduced egg production can be result of aflatoxins in layer houses.

A total commercial broiler feed $(n=96)$ samples collected from different broiler farms for the period June 2009 to May 2010 from south west Pakistan and analyzed for aflatoxin B1 (AfB1) by using thin layer chromatography with a detection limit of $3 \mu \mathrm{g} / \mathrm{kg}$. Analysis revealed that $91.66 \%$ samples of feed were positive. The levels of aflatoxins were ranged between 10 to $166 \mu \mathrm{g} / \mathrm{kg}$ with average of $47.64 \pm 2.55 \mu \mathrm{g} / \mathrm{kg}$. The findings showed the concentration levels of AFB1 were less in existing study as compared to findings of Rashid et al. (2012).

In another study analysis of 487 poultry samples collected from various parts of the Pakistan for detection of Aflatoxin B1 (AFB1) was carried out. The average and maximum levels of 23.75 and $78 \mu \mathrm{g} / \mathrm{kg}$ were reported respectively, However, maximum level of AFB1 was higher $(78 \mu \mathrm{g} / \mathrm{kg})$ in poultry feed samples. While in the existing study total 50 samples of poultry feed were studied with the 48 percentage of contamination with the highest level of $16.65 \mu \mathrm{g} / \mathrm{kg}$. The average contamination level recorded was $4.16 \pm 5.36 \mu \mathrm{g} / \mathrm{Kg}$ that was very low as compared to 
findings of Anjum et al. (2012).

In the present study, $0.5 \%$ hydrochloric acid was recorded as the best detoxifying agent along with heating up to $250^{\circ} \mathrm{C}$ at 10 minutes and boiling for 20 minutes. Even though, it is well known that the chemicals are good detoxifying agents but they reduce the nutritive value of feed item. A number of literature studies reported on physical and chemical approaches (washing, solvent extraction, heat treatment, extrusion, radiation, acid/base treatment, oxidation, and binding) that are in practice for eliminating or deactivating aflatoxins (Phillips et al., 1990; Samarajeewa et al., 1990; Basappa et al., 1996; Fandohan et al., 2005; Jubeen et al., 2020; Nazhand et al., 2020). However, most physical and chemical treatments have drawbacks such as reduced nutritional and sensory quality in processed foods, formation of hazardous chemicals during treatment, low efficiency, and high cost, which have limited their use (Mendez-Albores et al., 2005; Gowda et al., 2007; Burov and Trusov, 2010; Yazdanpanah et al., 2005).

Detoxification of aflatoxins by physical, chemicals, microbes and enzymes is normal practice that has been in practice from many years (Kumar et al., 2017; Lalah et al., 2019; Guan et al., 2021). Chemical additives such as citric, lactic, tartaric, and hydrochloric acids have also been a popular choice for the storage of food. However, other acids like succinic, acetic, ascorbic, and formic acid are only marginally efficient. These methods entail soaking infected items in acidic solutions for a specified period of time. High AFB1 degradation can be noticed in 24 hours or less, even when carried out at room temperature (Lee et al., 2015; Rushing and Selim, 2016; Safara et al., 2010). Similarly in my research it was observed that chemicals like calcium hydroxide and ammonia showed reduction in aflatoxins at their 5\% solution. However, Allameh et al. (2005) reported efficacy of aqueous ammonia against maize aflatoxins even at $1 \% \mathrm{v} / \mathrm{w}$. Most of the chemicals do not show results at their low concentrations as compared to $\mathrm{HCl}$ like sodium bisulphate which shows only $16 \%$ reduction percentage at its $1 \%$ solution. The hydrochloric acid is highly appreciated for its detoxifying abilities. It showed remarkable reduction percentage at its lower concentrations like $0.1,0.3$ and $0.5 \%$. The maximum reduction percentage was shown at $0.5 \%$ solution of $\mathrm{HCl}$ which was recorded as $58.4 \%$.

Another study on detoxification was performed by Khan and Zahoor (2014) to detoxify aflatoxin B1 in poultry feed by using a novel adsorbent that was prepared from bagasse a natural method. It was fed to different groups of poultry birds along with aflatoxin B1 and found very effective. The study supported that natural methods are better than both physical and chemical methods.
Wacoo et al. (2014) did a study to compare different methods such as thin-layer chromatography (TLC), high-performance liquid chromatography (HPLC), mass spectroscopy, enzyme-linked immune-sorbent assay (ELISA), and electrochemical immunesensor, for the detection of aflatoxins in foods. All the methods have limitations in aflatoxins analysis. In present study the TLC method was selected because it is simple to carry out also it is not much expensive. Soblev (2007) had stated that most of work that is going in recent years on separation, detection, and quantification of aflatoxins is going with the two techniques, TLC and HPLC and both of the techniques showed potential in detection of aflatoxin levels. Abiotic factors affects the levels of aflatoxins and more contaminated samples were recorded in months of July and September (temperature $15-39^{\circ} \mathrm{C}$ ) as compared to other months. However, a number of studies were in line with our results and also reported highest contamination with aflatoxins at $28^{\circ} \mathrm{C}$ and above temperatures particularly in tropical regions such as Asia and Africa (Boutrif, 1998; Abrar et al., 2013; Villers, 2014). According to Chiewchan et al. (2015) a maximum levels of aflatoxins were recorded at $12-40^{\circ} \mathrm{C}$.

The feed samples were from five different cities and it has been seen the Kasur city was the most affected with the aflatoxin contamination, as the contamination rate was recorded as $60 \%$. It might be due to poor storage conditions.

\section{CONCLUSION}

It was finally concluded that the contamination percentages of aflatoxins in broiler and layer feed samples were different and the detected amount was not much high. The feed samples from different cities showed different concentrations of aflatoxins and highest contamination percentage was detected in Kasur as compared to other cities. This study provide updated knowledge regarding to aflatoxins contamination. The study will provide good contribution to stakeholders such as poultry farmers and feed authorities so that they can prove regulations to provide good quality feed to poultry farms. This research also emphasizes on good storage conditions in poultry farms so that quality of feed can be improved.

\section{ACKNOWLEDGEMENTS}

We are extremely thankful to chairpersons of Lahore Garrison University, Lahore and PCSIR, Lahore for facilitating us during the research work.

\section{CONFLICT OF INTEREST}

There was no conflict of interest between authors. 


\section{AUTHORS CONTRIBUTION}

Khadija Summia did experimental work. Roheela Yasmeen was supervisor, planned the, research, helped in data analysis and write up of the manuscript, selection of journal, submission and entertaining the comments. Naseem Zahra was co-supervisor and facilitate the student in PCSIR.

\section{REFERENCES}

-Abidin Z, Khatoon A, Numan M (2011). Mycotoxins in broilers: pathological alterations induced by aflatoxins and ochratoxins, diagnosis and determination, treatment and control of mycotoxicosis. Worlds Poult. Sci. J. 67(3): 485-96. https://doi.org/10.1017/S0043933911000535

- Abrar M, Anjum FM, Butt MS, Pasha I, Randhawa MA, Saeed F, Waqas K (2013). Aflatoxins: biosynthesis, occurrence, toxicity, and remedies. Critic. Rev. Food Sci. Nut. 53(8): 86274. https://doi.org/10.1080/10408398.2011.563154

-Agag BI (2004). Mycotoxins in foods and feeds, 1-aflatoxins. Assiut University. Bull. Environ. Res. 7: 173-205. https:// doi.org/10.21608/auber.2004.150623

-Al-Hammadi S, Marzouqi F, Al-Mansouri A, Shahin A, AlShamsi M, Mensah-Brown E, Souid AK (2014). The cytotoxicity of aflatoxin B1 in human lymphocytes. Sultan Qaboos Uni. Med. J. 14(1): e65.

- Sahoo PK, Mukherjee SC (2001). Immunosuppressive effects of aflatoxin B1 in Indian major carp (Labeo rohita). Com. Immunol. Microbiol. Infect. Dis. 24(3): 143-149.

-Allameh A, Safamehr A, Mirhadi SA, Shivazad M, RazzaghiAbyaneh M, Afshar-Naderi A (2005). Evaluation of biochemical and production parameters of broiler chicks fed ammonia treated aflatoxin contaminated maize grains. Anim. Feed Sci. Technol. 122(3-4): 289-301. https://doi. org/10.1016/j.anifeedsci.2005.03.005

-Anjum MA, Hussain Z, Khan SH, Ahmad N, Amer MY, Iftikhar N (2014). Assessment of poultry feed ingredients used in commercial compound feed. Pak. J. Life Soc. Sci. 12: 69-73.

- Anjum MA, Khan SH, Sahota AW, Sardar R (2012). Assessment of aflatoxin B1 in commercial poultry feed and feed ingredients. J. Anim. Plant Sci. 22(2): 268-272.

-Basappa SC, Shantha T (1996). Methods for detoxification of aflatoxins in foods and feeds-a critical appraisal. J. Food Sci. Technol. 33(2): 95-107.

- Becha BB, Devi SS (2013). Aflatoxin levels in feeds and feed ingredients of livestock and poultry in Kerala. J. Vet. Med. Ani. Sci. 44: 76-78.

- Begum N, Adil R, Shah FH 1985. Contamination of groundnuts with Aflatoxins. Pak. J. Med. Res. 24: 129-131.

-Boutrif E (1998). Prevention of aflatoxin in pistachios. Food Nut. Agric. 32-37.

- Burov AE, Trusov YN (2010). Neutralization of aflatoxin B1 by ozone treatment and adsorption by nanodiamonds. Nanotechnol. Russia. 5(1): 137-141. https://doi. org/10.1134/S1995078010010143

- Chiewchan N, Mujumdar AS, Devahastin S (2015). Application of drying technology to control aflatoxins in foods and feeds: a review. Drying Technology. 33(14): 1700-1707. https:// doi.org/10.1080/07373937.2015.1068795

- Duncan HE, Hagler M (2008) Aflatoxins and other mycotoxins.
Oklahoma Cooperative Extension. Fact Sheet (CR-21051203), Oklahoma, USA.

-Fandohan P, Zoumenou D, Hounhouigan DJ, Marasas WF, Wingfield MJ, Hell K (2005). Fate of aflatoxins and fumonisins during the processing of maize into food products in Benin. Int. J. Food Microbiol. 98(3): 249-59. https://doi.org/10.1016/j.ijfoodmicro.2004.07.007

- GOP (Government of Pakistan) Economic survey of Pakistan (2014), Ministry of Finance, http://www.finance.gov.pk/ survey/chapters_14/02_Agriculture.pdf.

- Gowda NKS, Suganthi RU, Malathi V, Raghavendra A (2007). Efficacy of heat treatment and sun drying of aflatoxincontaminated feed for reducing the harmful biological effects in sheep. Anim. Feed Sci. Technol. 133: 167-175. https://doi.org/10.1016/j.anife

-Guan Y, Chen J, Nepovimova E, Long M, Wu W, Kuca K (2021). Aflatoxin Detoxification Using Microorganisms and Enzymes. Toxins. 13(1): 46. https://doi.org/10.3390/ toxins13010046

-Gunterus A, Roze LV, Beudr R, Linz JE (2007). Ethylene inhibits aflatoxins biosynthesis in Aspergillu parasiticus grow. J. Food Micrbiol. 24(6): 658-663. https://doi. org/10.1016/j.fm.2006.12.006

-Hegazy SM, Azzam A, Gabal MA (1991). Interaction of naturally occurring aflatoxins in poultry feed and immunization against fowl cholera. Poult. Sci. 70(12): 24258. https://doi.org/10.3382/ps.0702425

- Howorth B, Jr, Wyatt RD (1976). Effect of dietary aflatoxin on fertility, hatchability and progeny performance of broiler breeder hens. Appl. Environ. Microbiol.31:680-684. https:// doi.org/10.1128/aem.31.5.680-684.1976

-Hussain Z, Khan MZ, Khan A, Javed I, Saleemi MK, Mahmood S, Asi MR (2010). Residues of aflatoxin B1 in broiler meat: Effect of age and dietary aflatoxin B1 levels. Food Chem. Toxicol. 48: 3304-3307. https://doi.org/10.1016/j. fct.2010.08.016

-Jestoi M (2008). Emerging fusarium-mycotoxins fusaproliferin, beauvericin, enniatins, and moniliformin a review. Crit. Rev. J. Food Sci. Nutr. 48 (1): 21-49. https://doi. org/10.1080/10408390601062021

-Jubeen F, Sher F, Hazafa A, Zafar F, Ameen M, Rasheed T (2020). Evaluation and detoxification of aflatoxins in ground and tree nuts using food grade organic acids. Biocatalysis Agric. Biotechnol. 29: 101749. https://doi.org/10.1016/j. bcab.2020.101749

-Kabak B, Dobson ADW, Var I (2006). Strategies to prevent mycotoxin contamination of food and animal feed: a review. Crit. Rev. Food Sci. 46: 593-619. https://doi. org/10.1080/10408390500436185

- Kana JR, Gbemenou B, Gnonlonfin J, Harvey J, Wainaina J, Wanjuki I, Skilton RA, Teguia A (2013). Assessment of aflatoxin contamination of maize, peanut meal and poultry feed mixtures from different agroecological zones in Cameroon. Toxins. 5(5): 884-894. https://doi.org/10.3390/ toxins 5050884

- Khan FA,Zahoor M (2014). In vivo detoxification of aflatoxinB1 by magnetic carbon nanostructures prepared from bagasse. BMC Vet. Res. (1): 1-4. https://doi.org/10.1186/s12917014-0255-y

-Khan WA, Khan MZ, Khan A, Hussain I (2010). Pathological effects of aflatoxin and their amelioration by vitamin $\mathrm{E}$ in white leghorn layers. Pak. Vet. J. 30(3): 155-162.

- Kumar P, Mahato DK, Kamle M, Mohanta TK, Kang SG 
(2017). Aflatoxins: A global concern for food safety, human health and their management. Front. Microbiol. 7: 2170. https://doi.org/10.3389/fmicb.2016.02170

- Lalah JO, Omwoma S, Orony DA (2019). Aflatoxin B1: Chemistry, environmental and diet sources and potential exposure in human in Kenya. Aflatoxin B1 Occurrence, Detection and Toxicological Effects.

-Lee J,HerJY,Lee KG (2015). Reduction of aflatoxins (B1,B2,G1, and G2) in soybean-based model systems. Food Chem. 189: 45-51. https://doi.org/10.1016/j.foodchem.2015.02.013

-Mendez-Albores A, Arambula-Villa G, Loarca-Piña MG, Castano-Tostado E, Moreno-Martínez E (2005). Safety and efficacy evaluation of aqueous citric acid to degrade B-aflatoxins in maize. Food Chem. Toxicol. 43(2): 233-238 https://doi.org/10.1016/j.fct.2004.09.009.

- Nazhand A, Durazzo A, Lucarini M, Souto EB,Santini A(2020). Characteristics, occurrence, detection and detoxification of aflatoxins in foods and feeds. Foods. 9(5): 644. https://doi. org/10.3390/foods 9050644

- Neal GE, Judah DJ, Carthew P, Verma A, Latour I, Weir L, Coker RD, Nagler MJ, Hoogenboom LA (2001). Differences detected in vivo between samples of aflatoxin contaminated peanut meal, following by two ammonia based processes. Food Add. Contam. 18(2):137-149. https:// doi.org/10.1080/02652030010011379

- Oguz H (2012). Detoxification of aflatoxin in poultry feed: a review from experimental trials. Lohmann Information. 47(2):45-56.

- Ortatatli M, Oğuz H, Hatipoğlu F, Karaman M (2005). Evaluation of pathological changes in broilers during chronic aflatoxin (50 and $100 \mathrm{ppb}$ ) and clinoptilolite exposure. Res. Vet. Sci. 78(1): 61-68. https://doi.org/10.1016/j. rvsc. 2004.06 .006

- Owino JH, Ignaszak A, Al-Ahmed A, Baker PG, Alemu H, Ngila JC, Iwuoha EI (2007). Modeling of the impedimetric responses of an aflatoxins B1 immunosensor prepared on an electrosynthetic polyaniline platform. Anal Bioanal. Chem. 388 (5): 1069 - 1074. https://doi.org/10.1007/s00216-0071333-9

-Perrone G, Susca A, Cozzi G, Ehrlich K, Varga J, Frisvad JC, Meijer M, Noonim P, Mahakarnchanakul W, Samson RA (2007). Biodiversity of Aspergillus species in some important agricultural products. Stud. Mycol. 59: 53-66. https://doi. org/10.3114/sim.2007.59.07

- Phillips TD, Clement BA, Kubena LF, Harvey RB (1990). Detection and detoxification of aflatoxins: Prevention of aflatoxicosis and aflatoxin residues with hydrated sodium calcium aluminosilicate. Vet. Human Toxicol. 32: 15-19.

-Piva G, Galvano F, Pietri A, Piva A (2000). Detoxification methods of aflatoxins. Zootec. Intern. 23(7-8): 48-53.

-Pleadin J, Sokolovic M, Persi N, Zadravec M, Jaki V, Vulic A (2012). Contamination of maize with deoxynivalenol and zearalenone in Croatia. Food Control. 28(1): 94-8. https:// doi.org/10.1016/j.foodcont.2012.04.047

- Qazi JI, Fayyaz Z (2006). Aflatoxin contaminated foods and health risk perspective for Pakistani population. Mycopathol. 4: 27-34.

- Raphael JL, Rueda A, Lion KC, Giordano TP (2013). The role of lay health workers in pediatric chronic disease: a systematic review. Acad. Ped. 13(5): 408-20. https://doi.org/10.1016/j. acap.2013.04.015

- Rashid N, Bajwa MA, Rafeeq M, Khan MA, Ahmad Z, Tariq MM, Wadood A, Abbas F (2012) Prevalence of aflatoxin
B1 in finished commercial broiler feed from west central Pakistan. J. Anim. Plant Sci. 22(1):6-10.

- Romer TR, Campbell AD (1976). Collaborative study of a screening method for the detection of aflatoxins in mixed feeds, other agricultural products, and foods. J. Associ. Offic. Analyt. Chem. 59(1): 110-117.

-Rushing BR, Selim MI (2016). Effect of dietary acids on the formation of aflatoxin B2 as a means to detoxify aflatoxin B1. Food Addit. Contam. - Part A Chem. Anal. Control. Expo. Risk Assess. 33, 1456-1467. https://doi.org/10.1080 /19440049.2016.1217065

- Saeed MK, Zahra N, Hina S, Babar S, Ahmad I, Alim-un-Nisa SV, Ashraf M, Kalim I, Masood S (2020). Pak. J. Food Sci. 30(1): 18-23.

- Safara M, Zaini F, Hashemi SJ, Mahmoudi M, Khosravi AR, Shojai-Aliabadi F (2010). Aflatoxin detoxification in rice using citric acid. Iran. J. Pub. Health. 39: 24- 29

-Sahoo PK, Mukherjee SC (2001). Immunosuppressive effects of aflatoxin B1 in Indian major carp (Labeo rohita). Com. Immunol. Microbiol. Infect. Dis. 24(3): 143-149.

- Samarajeewa U, Sen AC, Cohen MD, Wei CI (1990). Detoxification of aflatoxins in foods and feeds by physical and chemical methods. J. Food Protec. 53(6): 489-501. https://doi.org/10.4315/0362-028X-53.6.489

- Shareef AM, Bayon OS, Qubih TS (2008). Correlation between broiler aflatoxicosis and European production efficiency factor. Iraqi J. Vet. Sci. 22: 49-55. https://doi.org/10.33899/ ijvs.2008.5670

- Shi Y, Xu Z, Sun Y, Wang C, Feng J (2009). Effects of two different types of montmorillonite on growth performance and serum profiles of broiler chicks during aflatoxicosis. Turk. J. Vet. Anim. Sci. 33: 15-20.

- Soblev VS (2007). Simple, rapid and inexpensive clean up method for quantitation of aflatoxins agricultural products by HPLC. J. Agric. Food Chem. 55(6): 36-41. https://doi. org/10.1021/jf063669j

- Van Egmond HP, Schothorst RC, Jonker MA (2007). Regulations relating to mycotoxins in food. Perspectives in a global and European context. Anal. Bioanal. Chem. 389 (1): 147157. https://doi.org/10.1007/s00216-007-1317-9

-Villers P (2014). Aflatoxins and safe storage. Front. Microbiol. 5: 158. https://doi.org/10.3389/fmicb.2014.00158

-Wacoo AP, Wendiro D, Vuzi PC, Hawumba JF (2014). Methods for detection of aflatoxins in agricultural food crops. J. Appl. Chem. (1-15): 706291. https://doi. org/10.1155/2014/706291

-WenLi C, Quan Z, Xing D (2008). Chemical detoxification of aflatoxin $\mathrm{B} 1$ in rice by several solutions through fluorescence spectral experiment. Key Eng. Mat. 364: 1032-1036. https:// doi.org/10.4028/www.scientific.net/KEM.364-366.1032

-Yazdanpanah H, Mohammadi T, Abouhossain G, Cheraghali AM (2005). Effect of roasting on degradation of aflatoxins in contaminated pistachio nuts. Food Chem. Toxicol. 43: 1135-1139. https://doi.org/10.1016/j.fct.2005.03.004

-Zahra N, Hina S, Ejaz N (2012). Detoxification of aflatoxin B1 in poultry and fish feed by various chemicals. Biol. Sci. PJSIR. 55(3):154-8. https://doi.org/10.52763/PJSIR. BIOL.SCI.55.3.2012.154.158

-Zinedine A, Juan C, Soriano JM, Molto JC, Idrissi L, Manes J (2007). Limited survey for the occurrence of aflatoxins in cereals and poultry feeds from Rabat, Morocco. Int. J. Food Microbiol. 115(1): 124-7. https://doi.org/10.1016/j. ijfoodmicro.2006.10.013 